\title{
FENOMENA BAHASA RESMI DALAM DOMAIN PENDIDIKAN
}

\author{
Nur Farida, Gigit Mujianto \\ Pendidikan Bahasa Indonesia , Fakultas Keguruan dan Ilmu Pendidikan \\ Universitas Muhammadiyah Malang \\ nurfarida1098@gmail.com
}

\begin{abstract}
ABSTRAK: Penelitian ini bertujuan untuk mengetahui situasi tutur dalam pemakaian bahasa resmi pada domain pendidikan. Untuk memenuhi tujuan tersebut, penelitian ini menggunakan jenis penelitian deskriptif dengan pendekatan kualitatif. Sumber data penelitian ini adalah tiga video dari situs jejaring youtube yaitu; Pertama youtube Mwira Albarizi yang berjudul Juara 2 Video Pembelajaran Bahasa Indonesia SMPN Banjit. Kedua, youtube SDN 1 Pringsewu Selatan yang berjudul Video Rapat Dewan Guru SD Negeri 1 Pringsewu Selatan. Ketiga, youtube Yoga 17 yang berjudul Contoh Video Negosiasi (Tugas Bahasa Indonesia) X MIPA 2. Data penelitian ini berupa kata-kata dan kalimat yang diucapkan oleh penutur dan mitra tutur yang ada dalam tanyangan video. Teknik pengumpulan data dilakukan dengan teknik simak-cata. Teknik analisis data yang digunkan dalam penelitian ini yaitu (1) penyajian data, (2) reduksi data, dan (3) penarikan kesimpulan. Hasil penelitian ini menunjukkan bahwa dalam pemakaian bahasa resmi pada domain pendidikan ditentukan dari tiga situasi yakni, hubungan peran, tempat peristiwa tutur, dan topik pembicaraan. Dalam pemakaian bahasa resmi pada domain pendidikan hubungan peran ini terjadi pada pendidik dengan peserta didik, kepala sekolah dengan dewan guru, dan antar teman. Tempat peristiwa tutur terjadi dalam domain pendidikan, seperti di dalam kelas, di ruang rapat, dan di lingkugan sekolah. Topik pembicaraan yang ditemukan sudah sesuai dengan pemakaian bahasa resmi dalam ranah pendidikan.

KATA KUNCI: Bahasa Resmi; Domain Pendidikan; Sosiolinguistik
\end{abstract}

\section{THE OFFICIAL LANGUAGE PHENOMENON IN THE EDUCATION DOMAIN}

ABSTRACT: This study aims to determine the situation of speech in the use use of official languages in the education domain. To fulfill that goal, this research uses descriptive research with a qualitative approach. The data source of this research is three videos from the youtube website namely; First, youtube Mwira Albarizi entitled Juara 2 Video Pembelajaran Bahasa Indonesia SMPN Banjit. Second, youtube SDN 1 Pringsewu Selatan entitled Video Rapat Dewan Guru SD Negeri 1 Pringsewu Selatan. Third, youtube Yoga 17 entitled Contoh Video Negosiasi (Tugas Bahasa Indonesia) X MIPA 2. The research data are in the form of words and sentences spoken by speakers and speech partners in the video. The technique of collecting data is done by listening-note it. Data analysis techniques used in this study are; (1) presenting data, (2) data reduction, and (3) drawing conclusions. The results of this study indicate that the use of official language in the education domain is determined from three situations namely, the role relationship, the place off speech, and the topic conversation. In the use of official languages in the education domain this role relationship occurs in educators with students, principals with the teacher council, and between friends. The scene of the speech occur in the education domain, such as in classroom, in meeting rooms, and in school environments. The topic of conversation was found to be appropriate for the use of official languages in the education domain.

KEYWORDS: Official Language; Education Domain; Sociolinguistic

\begin{tabular}{llll}
\hline Diterima: & Direvisi: & Disetujui: & Dipublikasi: \\
2020-05-02 & - & $2020-11-09$ & $2021-03-28$
\end{tabular}

Pustaka : Farida, N., \& Mujianto, G. (2021). Fenomena Bahasa Resmi dalam Domain Pendidikan. Fon : Jurnal Pendidikan Bahasa dan Sastra Indonesia, 17(1), 14-24. doi:https://doi.org/10.25134/fjpbsi.v17i1.2790

\section{PENDAHULUAN}

Dalam kehidupan sehari-hari, manusia tidak bisa terlepas dari bahasa. Bahasa merupakan alat komunikasi dengan manusia lainnya. Sebagai alat komunikasi, bahasa memiliki fungsi diantarannya alat untuk tukar-menukar informasi, alat untuk mengespresikan ide, dan alat untuk mempertahankan hubungan sosial. Tanpa bahasa, manusia tidak dapat melakukan interaksi sosial dengan manusia lainnya. Dalam kajian bahasa terdapat subdisiplin 
ilmu yaitu sosiolinguistik. Sosiolinguistik merupakan telaah bahasa dalam kaitannya dengan masyarakat. Sosiolinguitik juga merupakan bidang ilmu antardisiplin yang memperlajari bahasa dengan pengguna bahasa di dalam masyarakat yang berkaitan (Chaer dalam Rahmawati \& Sumarlam, 2016). Hal ini tidak lepas dari adanya dua aspek tingkah laku manusia yaitu penggunaan bahasa dan organisasi tingkah laku manusia (Fishman, dkk, dalam Rahmawati \& Sumarlam, 2016).

Komunikasi terjadi karena adanya suatu bahasa. Sebagaimana dinyatakan Sugeha, (2017, Hlm.126) bahwa bahasa digunakan sebagai sarana verbal sebagai terjalinnya kontak, interaksi, dan komunikasi untuk memenuhi kebutuhan manusia. Dalam berkomunikasi, bahasa mempunyai ragam atau variasi yang digunakan oleh masyarakat tuturnya. Herisetyanti, Suharyati, \& Rejeki (2019, Hlm. 1) berpendapat bahwa ragam atau variasi bahasa merupakan perbedaan cara berkomunikasi seseorang untuk mencapai tujuan yang sama. Ragam atau variasi bahasa tersebut terjadi karena adanya latar belakang budaya, sosial, dan situasi sehingga masyarakat tutur dapat menentukan penggunaan bahasanya (Sugeha, 2017).

Pada kenyataannya, semua manusia menggunakan ragam atau variasi bahasa yang berbeda yang dibedakan oleh beberapa faktor, salah satunya adalah faktor yang meliputi waktu dan situasi (Herisetyanti, Suharyati, \& Rejeki, 2019). Dalam situasi terdapat dua yang meggolongkan pemakaian bahasa yaitu situasi resmi dan tidak resmi. Bahasa yang digunakan pada situasi resmi menuntut penutur untuk menggunakan bahasa baku atau bahasa formal, sedangkan dalam situasi tidak resmi akan memunculkan suasana penggunaan bahasa yang tidak resmi yang terlihat dari keakraban penutur (Gunawan, 2013).

Salah satu faktor penentu dalam memilih bahasa adalah ranah atau domain. Dalam teori Fishman domain merupakan model lingkungan (Ibrahim, 2009). Ranah atau domain ini besumber pada penutur sebagai anggota masyarakat yang selalu berhubungan dengan anggota masyarakat lainnya. Berkaitan dengan ranah atau domain, Ibrahim, (2009, Hlm. 14) mengemukakan bahwa hubungan antaranggota masyarakat itu terjadi pada suatu tempat dan bertujuan untuk membicarakan sesuatu, serta bahasa bermanfaat sebagai alat komunikasi yang penting dalam pertemuan tersebut. Menurut Sugeha (2017, Hlm.128) bahwa ranah (domain) merupakan pertalian antara status partisipan tutur, latar peristiwa tutur, dan topik pembicaraan yang digunakan dalam pemakaian bahasa yang paling sesuai dengan lingkungannya.

Ranah atau domain yang relevan dalam suatu masyarakat menggolongkan tindak tutur dan peristiwa tutur ke dalam kelompok situasi sosial yang komponennya bersamaan dengan pemakaian bahasa atau ragam bahasa yang sesuai (Sugeha, 2017). Hal ini, biasanya berlaku karena adanya alih bahasa pada masyarakat aneka bahasa dan masyarakat diglosik. Dalam ranah yang berbeda maka pada pemakaian bahasa atau ragam bahasa yang berbeda pula. Menurut Fishman dalam Sartini (2015, Hlm. 55) menyatakan bahwa ada lima kategori ranah yang menyangkut kehidupan masyarakat, yaitu ranah keluarga (family domain), ranah ketetanggaan atau persaudaraan (friendship domain), ranah agama (religion domain), ranah pendidikan (education domain), dan ranah pekerjaan (employment domain).

Dalam penelitian ini lebih menekankan pada ranah (domain) pendidikan. Pendidikan merupakan suatu peran sangat penting dalam meningkatkan sumber daya manusia dan berkarakter dalam menjalani kehidupan sosial masyarakat global, baik pendidikan formal maupun non formal (Aziz, 2018). Peran bahasa dalam pendidikan sangat penting dalam berkomunikasi. Melalui komunikasi bahasa yang digunakan tercermin melalui struktur verbal atau tata cara berbahasa. Bahasa yang 
baik dan juga beretika adalah bahasa yang digunakan sesuai dengan norma kemasyarakatan yang berlaku. Misalnya, dalam situasi formal seperti dalam ranah pendidikan hubungan peran guru dengan peserta didik yang menggunakan bahasa resmi saat situasi di sekolah. Dalam ranah (domain) pendidikan sering kali menggunakan bahasa resmi yaitu bahasa baku dan bahasa formal. Ragam bahasa orang yang berpendidikan akan berbeda dengan orang yang tidak berpendidikan.

Penelitian mengenai bahasa resmi dalam domain pendidikan penting untuk dilakukan karena berbagai alasan. Pertama, pemakaian bahasa resmi dianggap sebagai bahasa yang wajib digunakan dalam ranah (domain) pendidikan. Kedua, pemakaian bahasa resmi dibutuhkan untuk mempersatukan masyarakat dari berbagai ragam bahasa atau variasi bahasa. Ketiga, setelah mengetahui bahwa pemakaian bahasa resmi sangat penting dalam ranah (domain) pendidikan, maka diharapkan terdapat penelitian pembaharuan untuk mengatasi permasalahan tersebut.

Penelitian yang mengenai bahasa resmi dalam ranah pendidikan belum pernah dilakukan, tetapi dalam ranah (domain) masih sedikit, salah satunya diteliti oleh Zulaeha (2017) dengan judul "Strategi Pemertahanan Bahasa Daerah pada Ranah Pendidikan" penelitian tersebut bertujuan untuk mengetahui karakteristik masyarakat tutur bahasa daerah, strategi pemertahanan bahasa daerah pada ranah pendidikan, pemertahanan bahasa daerah dalam pembelajaran, pemertahanan bahasa daerah melalui komunikasi atau ekstrakurikuler, pemertahanan bahasa daerah sebagai alat komunikasi wajib pada hari tertentu, dan fungsi pemertahanan bahasa daerah melalui pendidikan. Hasil menunjukkan bahwa pemertahanan dan pergeseran bahasa bagaikan dua sisi mata uang. Pemertahanan bahasa daerah tersebut dapat dilakukakan melalui pembelajaran; kegiatan komunitas atau ekstrakurikuler; dan alat komunikasi wajib pada hari tertentu. Hal itu berfungsi sebagai upaya mencegah pergeseran dan kepunahan bahasa daerah, mempersiapkan penutur bahasa daerah di masa depan, dan melestarikan budaya bangsa.

Penelitian ini juga dilakukan oleh Rahardi (2016) dengan judul "Manifestasi Wujud dan Makna Pragmatik Kefatisan Berbahasa dalam Ranah Pendidikan". Tujuan penelitian mendeskripsikan wujudwujud dan makna-makna pramatik kefatisan berbahasa yang terdapat dalam tindak berbahasa warga masyarakat Indonesia, khususnya di dalam ranah pendidikan. Hasil yang diperoleh yakni, (a) basa-basi dalam tuturan yang bermakna pragmatik penerimaan, (b) basa-basi dalam tuturan yang bermakna pragmatik penolakan, (c) basa-basi dalam tuturan yang bermakna pramagtik, (d) basa-basi dalam tuturan yang bermakna pragmatik pengucapan terima kasih, dan (e) basa-basi dalam tuturan yang bermakna pramagtik penyampaian salam.

Berdasarkan penelitian terdahulu yang telah ditemukan di atas, terdapat pembeda penelitian yang telah dilakukan. Bahwa penelitian ini berfokus pada pemakaian bahasa resmi dalam ranah (domain) pendidikan yang belum pernah diteliti pada peneliti sebelumnya. Berdasarkan paparan di atas, tujuan dalam penelitian ini berfokus untuk mengetahui situasi tutur dalam pemakaian bahasa resmi pada ranah (domain) pendidikan. Manfaat dari penelitian ini untuk memberikan rekomendasi atau gambaran bagi pembaca, pendidik, dan khususnya peserta didik dalam membina komunikasi yang baik dan benar sesuai dengan pemakaian bahasa resmi dalam ranah (domain) pendidikan.

\section{METODE}

Penelitian ini merupakan jenis penelitian deskriptif. Jenis penelitian deskriptif merupakan jenis penelitian yang dilakukan dengan cara menganlisis data yang sudah ada dan kemudian disusul dengan analisis data (Ratna, 2013). Menurut 
Moleong (2016, Hlm. 11) pendekatan kualitatif yang dilakukan dalam penelitian ini dengan cara deskriptif dalam bentuk kata, kalimat, frasa, dan bukan angka-angka.

Sumber data penelitian diperoleh dari tiga video yang diunduh ke situs video youtube yaitu; Pertama, youtube Mwira Albarizi yang berjudul Juara 2 Video Pembelajaran Bahasa Indonesia SMPN Banjit. Kedua, youtube SDN 1 Pringsewu Selatan yang berjudul Video Rapat Dewan Guru SD Negeri 1 Pringsewu Selatan. Ketiga, youtube Yoga 17 yang berjudul Contoh Video Negosiasi (Tugas Bahasa Indonesia) X MIPA 2. Data penelitian ini berupa kata dan kalimat yang diucapkan oleh penutur dan mitra tutur yang ada dalam tanyangan video tersebut.

Teknik pengumpulan data merupakan metode yang digunakan oleh peneliti untuk menggumpulkan data. Teknik penggumpulan data yang digunakan dalam penelitian ini yaitu teknik simak-catat. Teknik simak-catat dalam penelitian ini, peneliti mencatat data yang akan dihasilkan dalam pengamatan dan penyimakan dalam setiap peristiwa yang ada pada tujuan penelitian yang berada dalam video di situs jejaring youtube.

Intrumen penelitian merupakan alat atau fasilitas yang mempermudah peneliti untuk mengumpulkan atau memperoleh data dari subjek yang diteliti (Arikunto, 2010). Artinya, peneliti bertindak menjadi segalanya dari keseluruhan proses penelitian. Dalam penelitian ini intrumen yang digunakan berupa daftar tabel berisi kolom pengelompokan data sesuai dengan teori penelitian. Intrumen ini digunakan untuk memudahkan peneliti dalam menganalisis data penelitian.

Teknik analisi data merupakan penyusunan data secara sistematis tentang data yang di dapat dari hasil pengamatan. Teknik analisi data yang digunakan dalam penelitian ini adalah; (1) penyajian data, (2) reduksi data, dan (3) penarikan kesimpulan. Pertama, penyajian data merupakan langkah awal dalam mengolah dan mempersiapkan data berasal dari transkrip dialog antar penutur dalam video penelitian, serta data tersebut diklasifikasikan dan disusun berdasarkan ketergori masing-masing. Kedua, reduksi data dilakukan dengan menyaring ulang berbagai data yang diperoleh berdasarkan tujuan. Ketiga, penarikan kesimpulan merupakan langkah terakhir dalam analisis data dengan cara menginterprestasikan dan pemaknaan data yang telah dikumpulkan sesuai dengan teori yang digunakan.

\section{HASIL DAN PEMBAHASAN}

Hasil penelitian dalam pemakaian bahasa resmi digunakan pada situasi resmi seperti acara-acara penting terutama dalam ranah (domain) pendidikan. Pada ranah pendidikan pemakaian bahasa resmi wajib digunakan karena struktur bahasanya tertata rapi. Dalam penelitian ini, terdapat tiga polapola tingkah laku perilaku berbahasa yang dapat bersesuaian dengan ranah (domain) pendidikan yang diabstraksikan dari berbagai konteks institusional seperti, hubungan peran, tempat peristiwa tutur, dan topik pembicaraan. Hal itu, sesuai dengan pemakaian bahasa resmi dalam ranah (domain) pendidikan, yang ada pada data di bawah ini.

\section{Hubungan Peran Penutur dan Mitra Tutur}

Hubungan antara penutur-mitra tutur bergantung pada struktur sosial dan pranata sosial yang ada dalam peristiwa tutur. Dalam pemakaian bahasa resmi pada ranah (domain) pendidikan ini, hubungan peran terjadi pada pendidik, peserta didik, kepala sekolah, dan antar teman. Hubungan peran tersebut terjadi di lingkungan sekolah yang merupakan domain pendidikan. Hal ini, sesuai dengan data yang ditemukan dalam penelitian, adapun data tersebut adalah sebagai berikut. 
Pendidik : Masih ada yang ingat apa itu teks percobaan?

Semua Peserta Didik : Masih Bu.

Pendidik : Silakan berdiri Nak.

Peserta Didik 1 : Teks percobaan adalah teks yang bertujuan untuk memberikan informasi kepada halayak dan informasi tersebut berdasarkan hasil pengamatan.

Pendidik : Iya jawabannya benar anak-anak, berikan tepuk tangan. Sekarang struktur teks laporan percobaan masih ingat ada berapa?

Semua Peserta Didik : Masih Bu.

Pendidik : Dita sebutkan struktur teks yang pertama dan kedua apa?

Peserta Didik 2 : Pertama tujuan, yang kedua kajian teori.

Pendidik : Bagus anak-anak, berikan tepuk tangan. Baik anak-anak struktur teks berikutnya nomer tiga dan empat. Siapa yang ingin menjawab dan masih ingat? Yosi.

Berdasarkan data di atas menjelaskan tentang hubungan peran yang terjadi dalam ranah (domain) pendidikan. Hubungan peran yang ada dalam ranah pendidikan dilakukan oleh Pendidik sebagai penutur dan Peserta Didik sebagai mitra tutur. Hubungan peran antara Pendidik (penutur) dan Peserta Didik (mitra tutur) terjadi pada situasi pembelajaran.

Pembelajaran yang dilakukan oleh Pendidik (penutur) dan Peserta Didik (mitra tutur) termasuk dalam domain pendidikan. Peristiwa tutur yang terjadi dalam domain pendidikan ini menggunakan bahasa resmi. Pendidik (penutur) dan Peserta Didik (mitra tutur) harus menggunakan bahasa resmi karena terjadi di dalam pembelajaran. Bahasa resmi dianggap sangat cocok dalam ranah (domain) pendidikan. Hal ini karena pemakaian bahasa resmi dalam struktur bahasanya tertata rapi. Jadi penggunaan bahasa resmi dalam pembelajaran disebabkan oleh keresmian suasana penutur dan mitra tutur. Pemakaian bahasa resmi tidak hanya digunakan dalam pembelajaran saja, tetapi dalam pertemuan Kepala Sekolah dan Dewan Guru juga menggunakan bahasa resmi seperti pada kutipan di bawah ini.
Kepala Sekolah : Sekiranya itu yang dapat saya sampaikan untuk sementara ini. Ada hal-hal lain yang ingin disampaikan silakan saya beri waktu bagi yang ingin bertanya.

Dewan Guru 1 : Saya Bu ingin bertanya. Untuk pendampingan besok persyaratan yang akan di bawah apa saja $\mathrm{Bu}$ ?

Kepala Sekolah : Terima kasih Bu Juhariya, yang akan di bawah oleh Ibu di sana mungkin silabus dan RPP. Nanti di sana akan diberilan pembelakan. Silabus dan RPP Bapak Ibu dibuat seperti ini. Nanti ditanyakan jika ada kekurangan dan sebagainya. Nanti di sana akan diberikan pembekalan seperti apa RPP yang akan digunakan.

Dewan Guru 1 : Terima kasih Bu.

Kepala Sekolah : Iya, siapa lagi Bapak Ibu?

Dewan Guru 2 : Saya Bu.

Kepala Sekolah : Silakan.

Data di atas menggambarkan hubungan peran antara Kepala Sekolah sebagai penutur dan Dewan Guru sebagai mitra tutur. Hubungan peran ini terjadi karena Kepala Sekolah sebagai penutur memulai percakapan dengan memberi stimulus dan respon sehingga terjadi interaksi dalam peristiwa tutur. Interaksi yang dilakukan Kepala Sekolah (penutur) dan Dewan Guru (mitra tutur) terjadi dalam lingkungan sekolah.

Dalam hubungan peran ini Kepala Sekolah (penutur) dan Dewan Guru (mitra tutur) dalam dialognya menggunakan bahasa resmi. Bahasa resmi digunakan untuk memperlancar jalannya interaksi. Hal ini terjadi karena dalam hubungan peran Kepala Sekolah (penutur) dan Dewan Guru (mitra tutur) merupakan ranah (domain) pendidikan sehingga bahasa yang digunakan harus bahasa resmi. Selain itu, pemakaian bahasa resmi juga bisa digunakan oleh antar teman seperti berikut.

Mei : Apakah kamu serius Ren?

Rena : Iyam aku serius tetapi jika boleh tahu bagaimana sistem pembayarannya?

Mei : Untuk tiga jam seharga Dua Ratus Empat Puluh Ribu.

Rena : Berarti satu jan seharga Delapan Puluh

Ribu ya?

Mei : Iya Ren. 
Rena : Aduh, itu terlalu mahal. Bagaimana kalau Lima Puluh Ribu perjam?

Mei : Maaf sebelumnya, belum bisa dengan harga segitu, harga segitu saya gunakan untuk menyewa fasilitas.

Rena : Emm, bagaimana kalau dengan harga Enam Puluh Lima Ribu?

Mei : Maaf belum bisa, saya kasih harga Tujuh Puluh Lima Ribu deh.

Dari dialog di atas merupakan hubungan peran yang terjadi antar teman yaitu Mei sebagai penutur dan Rena sebagai mitra tutur. Dalam ranah (domain) pendidikan hubungan peran ini tidak hanya terjadi pada Guru dan Kepala Sekolah sebagai penutur dan mitra tutur, tetapi hubungan peran juga terjadi antar teman. Hal ini terjadi karena dalam hubungan peran antar teman itu terjadi pada domain pendidikan.

Hubungan peran antar teman dalam data ini terjadi di lingkunga sekolah yang termasuk dalam ranah pendidikan. Hal ini, terjadi hubungan peran dalam ranah pendidikan sangat berpengaruh pada interaksi penutur dan mitra tutur untuk menggunkan bahasa resmi dalam percakapannya, meskipun dengan teman sebaya. Pemakaian bahasa resmi dalam ranah (domain) pendidikan ini sangat berperan penting dalam interaksi antar penutur dan mintra tutur.

Dari hasil analisis data yang ditemukan, hubungan peran dalam pemakaian bahasa resmi pada domain pendidikan terjadi antara pendidik dan peserta didik, kepala sekolah dan dewan guru, serta terjadi antar teman. Hubungan peran tersebut terjadi di lingkungan sekolah yang termasuk dalam domain pendidikan. Pada ranah (domain) pendidikan penutur dan mitra tutur menggunakan bahasa resmi yang membuat komunikasi berjalan dengan baik. Hal ini sejalan menurut Fishman dalam Ibrahim (2009, Hlm. 14) menyatakan bahwa hubungan peran itu terjadi pada suatu tempat dan bertujuan untuk membicarakan sesuatu, serta bahasa resmi bermanfaat sebagai alat komunikasi yang penting dalam hubungan peran tersebut.

Pemakaian bahasa resmi dari analisis data yang ditemukan penutur dan mitra tutur mampu menggunakan bahasa yang baik dan benar, terutama dalam ranah (domain) pendidikan. Hal itu, karena dalam pemakaian bahasa resmi penggunaan tutur katanya sopan. Penelitian releven oleh Rahayu (2015, Hlm. 12) menjelaskan bahwa Bahasa resmi merupakan ragam bahasa yang digunakan dalam dunia pendidikan berupa buku pembelajaran, buku-buku ilmiah, dalam pertemuan resmi, administrasi negara, perudang-undangan, dan wacana teknis yang harus sesuai dengan kaiadah bahasa.

\section{Tempat Peristiwa Tutur}

Peristiwa tutur menunjukkan lokasi atau tempat yang mempengaruhi pemilihan bahasa atau variasi bahasa. Dalam ranah atau domain pendidikan tempat peristiwa tutur terjadi di lingkungan sekolah seperti, di dalam kelas dan ruang pertemuan atau rapat. Hal ini, sesuai dengan ranah (domain) pendidikan sebagai berikut.

Pendidik : Selamat pagi anak-anak.

Peserta Didik : Selamat pagi Bu.

Pendidik : Siap belajar anak-anak?

Peserta Didik : Siap Bu.

Pendidik : Anak-anak sebelum kita belajar. Supaya kita tetap belajar dengan nyaman, kita harus lakukan operasi adiwiyata dulu. Siap?

Peserta Didik : Siap Bu.

Pendidik :Silakan bersikan anak-anak, yang ada sampahnya langsung buang ke tempat sampah, yang tidak ada kembali duduk dengan rapi. Anak-anak sudah bersih semua?

Peserta Didik : Sudah Bu.

Berdasarkan data tersebut tempat peristiwa tutur terjadi di dalam kelas. 
Dalam kelas merupakan bagian dari domain pendidikan. Hal ini, terjadi karena tempat peristiwa tutur dipengaruhi oleh pemilihan bahasa atau variasi bahasa. Dialog yang ditemukan dalam pembelajaran ini menerangkan tempat peristiwa tutur yang disampaikan oleh tuturan penutur seperti "Anak-anak sebelum kita belajar. Supaya kita tetap belajar dengan nyaman, kita harus lakukan operasi adiwiyata dulu”.

Dari dialog tersebut sudah sangat jelas bahwa peristiwa tutur terjadi dalam kelas. Dialog yang menerangkan tempat peristiwa tutur tersebut menggunakan bahasa resmi. Pengunaan bahasa resmi itu disebabkan oleh keresmian suasana penutur dan mitra tutur yang menuntut adanya bahasa resmi. Dalan tempat peristiwa tutur yang terjadi dalam ranah pendidikan ini, pemakaian bahasa resmi tidak hanya terjadi dalam kelas saja. Di ruang pertemuan atau ruang rapat juga menggunakan bahasa resmi seperti data di bawah ini.

Kepala Sekolah : Assalamualaikum Wr Wb. Dewan Guru : Waalaikumsalam Wr Wb.

Kepala Sekolah : Alhamdulillah, mari kita panjatkan kehadiran Allah SWT karena atas rahmat dan hidayahya sehingga kita pada pagi menjelang siang ini dapat berkumpul di ruang ini dengan keadaan sehat walafiat.

Data di atas menjelaskan tentang tempat peristiwa tutur. Tempat terjadinya peristiwa tutur yang dilakukan oleh Kepala Sekolah dan Dewan Guru terjadi di ruang rapat. Hal itu, sangat jelas ketika Kepala Sekolah mengucapkan kalimat "Pada pagi menjelang siang ini dapat berkumpul di ruang ini dengan keadaan sehat walafiat". Dari kata ruang menjelaskan bahwa Kepala Sekolah dan Dewan Guru berada pada situasi tempat terjadinya peristiwa tutur.

Dalam ranah (domain) pendidikan ini peristiwa yang dilakukan oleh Kepala Sekolah dan Dewan Guru terjadi di lingkungan sekolah tepatnya di ruang rapat. Hal ini, didukung adanya hubungan peran antara Kepala Sekolah dan Dewan Guru sehingga sangat jelas bahwa tempat peristiwa tutur itu terjadi di domain pendidikan. Dalam domain pendidikan ini Kepala sekolah dan Dewan Guru menggunakn bahasa resmi. Pemakaian bahasa resmi ini terjadi karena Kepala Sekolah dan Dewan Guru masih terikat dalam ranah pendidikan sehingga tempat peristiwa tutur ini dipengaruhi oleh variasi bahasa. Selain itu, dalam lingkungan sekolah penutur dan mitra tutur harus menggunakan bahasa resmi seperti interaksi yang terjadi antar teman sebagai berikut.

Rena : Baiklah saya akan menghubungi kamu hari kamis.

Mei : Baik, terima kasih Rena.

Rena : Sama-sama Mei, saya akan kembali ke kelas dulu ya.

Mei : Baik, hati-hati ya.

Pada data di atas menggambarkan tentang tempat terjadinya peristiwa tutur. Data yang ditemukan dalam hubungan peran antar teman ini terjadi di lingkungan sekolah. Hal ini didukung oleh ucapan Rena sebagai mitra tutur seperti "Sama-sama Mei, saya akan kembali ke kelas dulu ya". Dari kata kelas memperlihatkan bahwa peristiwa tutur terjadi di lingkungan sekolah. Lingkungan sekolah yang terjadi antar teman tersebut termasuk dalam domain pendidikan.

Dalam peristiwa tutur ini yang terjadi pada antar teman ini menggunakan bahasa resmi. Meskipun dalam hubungan peran antar teman, jika interaksi terjadi di lingkungan sekolah maka penutur dan mitra tutur harus menggunakan bahasa resmi. Hal ini, terjadi karena hubungan peran antar teman ini terjadi di dalam domain pendidikan sehingga dianjurkan menggunakan bahasa resmi meskipun antar teman.

Dalam analisis data yang ditemukan tempat peristiwa tutur dalam pemakaian bahasa resmi pada domain pendidikan 
ditemukan di dalam kelas pada situasi pembelajaran, di ruang rapat atau ruang pertemuan, dan di lingkungan sekolah. Data yang di dapat tersebut termasuk dalam domain pendidikan. Hal ini, karena tempat peristiwa tutur yang dilakukan penutur dan mitra tutur tersebut terjadi pemilihan bahasa sesuai dengan situasinya. Sejalan dengan pendapat Saragih (2018, Hlm. 4) bahwa situasi tempat peristiwa tutur menentukan ragam bahasa yang dipilih oleh penutur dan mitra tutur dalam komunikasinya.

Dalam tempat terjadinya peristiwa tutur ini penutur bertingkah laku, termasuk berbahasa sesuai dengan polapola yang berlaku dalam masyarakat tutur. Menurut Fishman (dalam Ibrahim, 2009) berpendapat bahwa tempat terjadinya peristiwa tutur sangat berpengaruh terhadap pemilihan bahasa atau variasi bahasa. Oleh karena itu, pemakaian bahasa resmi ini dianggap cocok pada situasi dalam ranah (domain) pendidikan.

\section{Topik Pembicaraan Peristiwa Tutur}

Topik pembicaraan ini menunjukkan hubungan latar belakang penutur dengan topik pembicaraan dalam pemilihan dan penggunaan bahasa. Dalam ranah (domain) pendidikan, topik pembicaraan harus sesuai dengan lingkungan sekolah dan pemakaian atau penggunaan bahasa resmi yang terdapat pada kutipan berikut ini.

Pendidik : Hari ini anak-anak kita akan mempelajari struktur teks, namun kita akan menelaah teks yang ibu siapkan. Ibu menyiapkan sebuah teks yang berjudul tentang membuat tempe. Kemudian nanti kalian telaah secara berkelompok. Siap semua?

Peserta Didik : Siap.

Dari data di atas peristiwa tutur terjadi karena adanya topik pembicaraan. Topik pembicaraan yang disampaikan oleh Pendidik tersebut mengarah pada situasi pembelajaran. Dalam situasi pembelajaran tersebut termasuk dalam ranah (domain) pendidikan. Topik pembicaraan dalam pembelajaran ini adalah menelaah struktur teks percobaan. Pada topik pembicaraan ini terjadi karena hubungan latar belakang penutur sehingga terjadi pemilihan dan penggunaan bahasa.

Adanya topik pembicaraan ini menimbulkan adanya peristiwa tutur yang mengaruh pada ranah (domain) pendidikan. Dalam topik yang disampaikan oleh Pendidik menggunakan bahasa resmi. Bahasa resmi sering kali digunakan dalam pembelajaran yang mempermudah Peserta Didik memahami apa yang disampaikan oleh Pendidik.

Selain itu, topik pembicaraan yang terjadi dalam ranah (domain) pendidikan dalam pemakaian bahasa resmi tidak hanya digunakan dalam pembelajaran saja, tetapi dalam topik pembicaraan yang menyangkut dalam ranah (domain) pendidikan juga harus menggunakan bahasa resmi seperti data yang ditemukan di bawah ini.

Kepala Sekolah : Bapak Ibu yang saya hormati pada kesempatan ini saya akan menyampaikan yaitu jadwal kegiatan pendampingan kuriklum 2013 yang akan dilaksanakan di SD Negeri 3 Pringsewu Barat.

Dalam data di atas topik pembicaraan yang dibahas yaitu tentang jadwal kegiatan pendampingan kurikulum 2013. Topik pembicaraan tersebut dilakukan oleh Kepala Sekolah dan Dewan Guru. Topik pembicaraan yang dilakukan oleh Kepala Sekolah dan Dewan Guru terjadi di lingkungan sekolah sehingga topik pembicaraannya sesuai dengan penggunaan bahasa resmi.

Topik pembicaraan Kepala Sekolah dan Dewan Guru ini termasuk dalam ranah (domain) pendidikan. Pada ranah (domain) pendidikan yang sesuai dengan topik pembicaraan yang dilakukan Kepala 
Sekolah dan Dewan Guru ini menggunakan bahasa resmi. Hal itu, terjadi karena Kepala Sekolah dan Dewan Guru membicarakan topik tersebut di lingkungan sekolah.

Selain itu, topik pembicaraan terjadi karena hubungan latar belakang penutur sehingga terjadi pemilihan bahasa. Jadi topik pembicaraan dan bahasa yang digunakan harus sesuai dengan persitiwa tutur. Topik pembicaraan yang terjadi dalam domain pendidikan ini pada pemakaian bahasa resmi digunakan antar teman sebaya yang terjadi dalam lingkungan sekolah, seperti percakapan di bawah ini.

Mei : Oh, itu Rena. Selamat sore Rena kamu sedang apa?

Rena : Selamat sore Mei, saya sedang baca buku, ada apa?

Mei : Mohon maaf sebelumnya kedatangan saya ke sini untuk mempromosikan karya ilmiah remaja khususnya untuk bidang les privat. Siapa tahu kamu tertarik dengan les privat ini.

Berdasarkan data tersebut menceritakan tentang topik pembicaraan yang dilakukan penutur dan mitra tutur. Topik pembicaraan yang ditemukan dalam data ini yaitu mempromosikan karya ilmiah dalam bidang les privat. Dalam topik pembicaraan ini dilakukan oleh hubungan peran antar teman.

Topik pembicaraan tersebut terjadi karena penutur dan mitra tutur mendapatkan tugas negosiasi sehingga menggunakan bahasa resmi. Bahasa resmi ini digunakan karena peristiwa tutur terjadi di lingkungan sekolah yang masih dalam ranah (domain) pendidikan. Pada topik pembicaraan yang dilakukan oleh hubungan antar teman ini sesuai dengan pemakaian bahasa resmi. Hal ini, disebabkan karena latar belakang penutur dan mitra tutur peristiwa dalam ranah pendidikan sehingga cocok menggunakan bahasa resmi, meskipun antar teman.
Topik pembicaraan yang ditemukan dari analisis data yaitu penutur dan mitra tutur menggunakan topik yang sesuai dengan situasi yang ada pada ranah (domain) pendidikan. Situasi dalam domain pendidikan seperti dalam situasi pembelajaran, situasi rapat atau pertemuan dewan guru, dan situasi antar teman saat membicarakan tugas. Situasi tersebut terjadi di dalam lingkungan sekolah sehingga pemakaian bahasanya menggunakan bahasa resmi untuk tejadinya suatu percakapan.

Dalam pemakaian bahasa resmi pada ranah (domain) pendidikan yang ditemukan dari analisi data, bahwa topik pembicaraan yang dilakukan penutur dan mitra tutur harus sesuai dengan topik yang dibicarakan, menurut hubungan pembicara, kawan bicara, dan orang yang dibicarakan. Hal ini, sejalan dengan pendapat Saragih (2018. Hlm. 5) bahwa dalam pemakaian ragam bahasa dipengaruhi oleh pokok pembicaraan, tujuan dan arah pembicaraan, serta sikap pembicaraan. Segi-segi itulah yang membedakan ragam ini menjadi ragam resmi.

Pemakaian bahasa resmi dalam topik pembicaraan sangat penting untuk menjalani suatu hubungan sosial yaitu selain bahasa digunakan sebagai alat komunikasi, bahasa juga dapat digunakan sebagai alat untuk bertukar pendapat atau gagasan kepada orang lain. Topik pembicaraan yang ditemukan dari analisis data terjadi pada pendidik dengan peserta didik, kepala sekolah dengan dewan guru, serta antar teman. Dari pemakaian bahasa resmi yang di gunakan kelompok penutur berpendidikan tanpak jelas perbedaanya dengan yang digunakan oleh kelompok penutur tidak berpendidikan (Saragih, 2018). Artinya bahwa dalam pemakaian bahasa resmi pada ranah (domain) pendidikan ini, apa yang dibicarakan akan sesuai dengan ranahnya, sebaliknya pemakaian bahasa resmi tidak dapat 
digunakan dalam situasi yang tidak resmi. Jadi, tidak ada keseragaman antara penutur yang satu dengan penutur yang lain dalam pemakaian bahasa resmi untuk membicarakan topik-topik tertentu.

\section{KESIMPULAN}

Berdasarkan hasil analisis yang telah dilakukan dalam penelitian ini, dapat disimpulkan bahwa fenomena pemakaian bahasa resmi dalam ranah (domain) pendidikan terjadi karena hubungan peran penutur dengan mitra tutur, tempat peristiwa tutur, dan topik pembicaraan yang dilakukan penutur dan mitra tutur. Dalam pemakaian bahasa resmi pada ranah (domain) pendidikan ini sudah sesuai dengan situasi pemilihan dan penggunaan bahasa. Hal ini, karena dalam pemakaian bahasa resmi pada ranah (domain) pendidikan hubungan peran terjadi antara pendidik dengan peserta didik, kepala sekolah dengan dewan guru, dan antar teman. Tempat pertiwa tutur yang terjadi dalam ranah (domain) pendidikan dilakukan di dalam kelas, ruang rapat atau ruang pertemuan, dan terjadi di lingkungan sekolah. Topik pembicaraan yang dilakukan oleh penutur dan mitra tutur ini sudah sesuai dengan pemakaian bahasa resmi yang terjadi pada ranah (domain) pendidikan. Data yang ditemukan dari analisis data tersebut terlihat bahwa dalam pemakaian bahasa resmi sudah sesuai dengan situasi yang digunakan pada ranah (domain) pendidikan.

\section{DAFTAR PUSTAKA}

Arikunto, S. (2010). ProsedurPenelitian Suatu Pendekatan Praktik. Jakarta: PT. Rineka Cipta.

Aziz, A. (2018). Landasan Pendidikan. Cirendeu Ciputat: HAJA Mandiri.

Gunawan, F. (2013). Implikasi Penggunaan Bahasa Gaul terhadap Pemakaian Bahasa Indonesia di
Kalangan Siswa SMAN 3 Kendari . Al-Izzah, 8(1), 56-72.

Herisetyanti, T., Suharyati, H., \& Rejeki, S. (2019). Ragam Bahasa dalam Komponen Tutur. Media Bahasa, Sastra, dan Budaya Wahana. 25(2), $1-15$.

Ibrahim, A. S. (2009). Kesemestaan Sosiolinguistik. Malang: Departemen Pendidikan Nasional Universitas Negeri Malang.

Moleong, L. (2016). Metode Penelitian Kualitatif. Bandung: PT. Remaja Rosdakarya.

Mwira Albarizi. (30 Maret 2020). Juara 2 Video Pembelajaran Bahasa Indonesia SMPN BANJIT. Youtube. https://www.youtube.com/watch?v= ORTh-yz4j0U\&t $=459 \mathrm{~s}$

Rahardi, R. K. (2016). Manifestasi Wujud dan Makna Pragmatik Kefatisan Berbahasa dalam Ranah Pendidikan. Jurnal Bahasa Dan Sastra, 15(2), 226-245.

Rahayu, A. P. (2015). Menumbuhkan Bahasa Indonesia yang Baik dan Benar dalam Pendidikan dan Pengajaran. PARADIGMA, 2(1), 115.

Rahmawati, F. P., \& Sumarlam. (2016). Variasi Bahasa pada Tayangan Kick Andy dalam Episode Ngelmu Sampai Mati. Kajian Linguistik Dan Sastra, 1(2), 137-145.

Ratna, N. K. (2013). Teori, Metode, dan Teknik Penelitian Sastra. Yogyakarta: Pustaka Belajar.

Saragih, D. K. (2018). Bahasa dan Ragam Bahasa pada Pendidikan Anak Sekolah. Paradigma Lingua, 6(2), $1-11$.

Sartini, N. W. (2015). Perilaku Bahasa Diaspora Orang Bali di Jawa Timur: Kajian Sosiolinguistik. KEMBARA, 1(1), 54-62.

Sdn1 Pringsewu Selatan. (7 April 2020). Video Rapat Dewan Guru SD Negeri 1 Pringsewu Selatan. 
\begin{tabular}{ll|llll} 
Youtube. & https://youtu.be/I5vj- & $\mathrm{X}$ & MIPA & 2. & Youtube.
\end{tabular} Bwialvl . $\quad$ https://youtu.be/PtSkNE9C2V4 .

Sugeha, A. Z. (2017). Variasi Pilihan Zulaeha, I. (2017). Strategi Pemertahanan Bahasa pada Masyarakat di Kabupaten Probolinggo: Kajian Etnografis. Etnolingual, 1(1), 125Bahasa Daerah pada Ranah Pendidikan. Peradaban Melayu, 12, 144.

Yoga 17. (7 April 2020). Contoh Video Negosiasi (Tugas Bahasa Indonesia) 40-46. 